\title{
A CULPA É DOS DIREITOS HUMANOS. O BRASIL NA FICÇÃO DE ANDRÉ SANT'ANNA
}

\author{
POR \\ Carlos Cortez Minchillo \\ Dartmouth College
}

A mais terrivel de nossas heranças é esta de levar sempre conosco a cicatriz de torturador impressa na alma e pronta a explodir na brutalidade racista e classista.

Darcy Ribeiro, O povo brasileiro

"Nós é que achamos que bom era no tempo da ditadura". A frase abre o conto "Nós somos bons", de André Sant'Anna, e soa como afronta, dada sua franca leviandade em relação a um dos períodos mais violentos da história brasileira. Em chave ficcional, a boutade é compreensível e até risível, introduzindo um retrato evidentemente irônico da mentalidade de setores da sociedade brasileira que, a despeito do que a história do país tem a ensinar, acreditam que "os militares governavam bem, desenvolviam o país, geravam emprego, geravam renda" ("Nós somos" 27). ${ }^{1} \mathrm{Na}$ obra de Sant'Anna, a ditadura não é exclusivamente ambiente ou referência localizados no passado. $\mathrm{O}$ autor põe o dedo em feridas que estão presentemente abertas, como um sistema social radicalmente excludente, a brutalidade assassina da polícia e de grupos de extermínio, que fazem de negros e pobres seu alvo preferencial, e a incapacidade do sistema judicial em garantir agilidade, imparcialidade e transparência na aplicação da lei. Se esses não são problemas criados pelo regime civil-militar implantado em 1964, reconhece-se que durante os governos militares a lógica abusiva da doutrina de segurança nacional, transformando cidadãos em inimigos do Estado, sedimentou uma cultura do arbítrio, do desmando e da violência (Napolitano 129-34). A política econômica, por sua vez, recorrendo ao arrocho salarial e à concentração de renda como pilares do crescimento, produziu um sentimento de satisfação nas classes médias às custas da desolação e marginalização das classes populares (Napolitano 148). Por isso, constrange e preocupa que a defesa disfarçada ou explícita da ditadura tenha recentemente ganhado as ruas das

As citações dos textos de André Sant'Anna serão identificadas pelos títulos dos contos que compõem $O$ Brasil é bom. 
cidades brasileiras. O pedido de intervenção das Forças Armadas surgiu em vários dos protestos que, desde 2013, deram voz a uma difusa gama de reivindicações, aquecendo o clima político e social do país e reencenando na esfera pública uma virulenta polarização ideológica que foi igualmente a tônica do período pré-golpe de 64 e cujas manifestações mais extremadas pareciam ter desaparecido sob o influxo do ambiente democrático. Sant'Anna, nos textos que compõem O Brasil é bom-quatro dos quais fazem referência direta ao regime militar-, capta as trepidações do momento atual, enxergando sob as recentes transformações político-sociais no país as reverberações de um passado comprometedor.

Como bem se sabe, durante o período da ditadura, a violência de Estado no Brasil se institucionalizou em níveis sem precedentes. As práticas de terror do regime golpista, em parte amparadas por uma legislação antidemocrática de exceção e em parte alheias a qualquer racionalidade, provocaram tragédias individuais e familiares irreparáveis, e prejuízos coletivos de longo alcance. O sequestro, encarceramento, tortura e assassinato de opositores, a repressão e dizimação oportunista de setores sociais, a restrição sistemática aos direitos civis não apenas golpearam implacavelmente os grupos organizados de mobilização política, mas consolidaram uma cultura de casuísmo, barbárie e opressão que ainda hoje tende a formatar o modus operandi das instituições públicas e privadas no Brasil, assim como relações interpessoais nos mais variados âmbitos da vida social do país. Promovido a partir do final da década de 1970, o processo de redemocratização foi lento e gradual não só porque esteve sob estratégico controle do regime autoritário, mas também porque significou restabelecer a duras penas práticas e discursos de defesa de direitos humanos, sistematicamente subtraídos durante as mais de duas décadas de regime repressor.

Trinta e um anos depois do fim do período de exceção, observa-se com assombro o fortalecimento de discursos ultraconservadores que só aparentemente haviam entrado em latência em função dos esforços de indivíduos e entidades que arduamente trabalharam pela restituição da cidadania democrática. São muitos os indícios daquilo que alguns têm identificado como a emergência de uma nova direita (Saad-Filho e Boito 213). Em 2015, por exemplo, em sessão da Comissão de Direitos Humanos e Minorias da Câmara dos Deputados que analisava a atividade policial no país, o deputado Jair Bolsonaro declarou desejar que a Polícia Militar matasse "duzentos mil vagabundos". E completou: "[s]e um dia eu tiver poderes para tal, não vai ter um centavo para ONG, um centavo para qualquer órgão relacionado a direitos humanos" ("Audiência pública" 34). Desta forma, na mesma proporção que setores oprimidos e economicamente desfavorecidos da população brasileira têm se organizado e conquistado visibilidade política e algum espaço social nestes anos pós-ditadura-e provavelmente justamente por isso-vozes reacionárias têm voltado a expor, ainda uma vez e com grande truculência e alarde, os profundos veios hierárquicos, elitistas e autoritários da sociedade brasileira

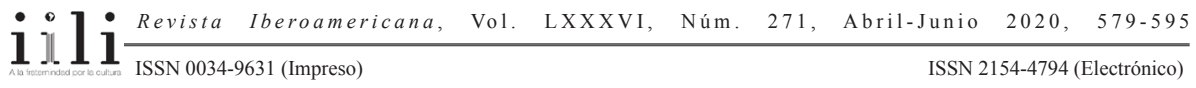


(Chauí 158-61). Como nos tempos que imediatamente precederam o golpe militar, a esquerda passou a ser demonizada em termos simplistas, e voltaram à tona, embalados em sentimento patriótico salvacionista e em loas ao mercado neoliberal, velhos lemas que justificaram a tomada de poder pelos militares e o sombrio regime de exceção que se seguiu. O narrador de um dos contos de Sant'Anna resume os alegados motivos da "revolução" de 64, satirizando seu caráter conservador e o eufemismo com que os próprios responsáveis batizaram o golpe: "[...] até que uma junta militar empossou o marechal Castelo Branco na presidência da República, e o Brizola e o Jango e o Juscelino, e até mesmo o Carlos Lacerda, passaram a ser considerados todos eles inimigos da revolução (rá rá rá), da liberdade, da pátria, da família, de Deus, essas porra" (Sant'Anna, "História da revolução" 128).

Entre ataques e contra-ataques, trava-se hoje nas ruas, na mídia e nas redes sociais uma batalha discursiva que tem alterado a forma como a sociedade brasileira concebe e representa a si mesma. Exibem-se agora sem disfarces as fraturas de classe e raça que histórica e ideologicamente foram mascaradas sob o clichê de uma sociedade coesa em seus interesses e harmônica na sua convivência, na qual o dissenso político e a mobilização da sociedade civil foram quase sempre estigmatizados e reprimidos, especialmente mas não só quando sob o jugo das Forças Armadas (Dreifuss e Dulci 138-39). No plano político, parece ter-se desfeito o pacto de governabilidade composto no período de redemocratização do país e que, segundo Marcos Nobre, blindou o sistema político contra a sociedade e travou as "grandes transformações, reprimindo as diferenças sob uma nova unidade forçada" (7). Segundo o sociólogo Gabriel Feltran, "[o] que se percebe, transitando entre favelas e elites, é que a metáfora da guerra (inimigos a combater) parece fazer mais sentido para pensar a política hoje do que a metáfora da democracia (comunidade de cidadãos)". A partir das manifestações de 2013, uma caixa de Pandora parece ter sido aberta: o Brasil revelou seus contrastes e conflitos numa cacofonia que está literariamente representada em $O$ Brasil é bom.

Para Flora Süssekind, o livro de Sant'Anna propõe o "ventriloquismo de uma classe média truculenta e raivosa". Efetivamente, nos moldes do plurilinguismo bakhtiniano, os textos de Sant'Anna flagram, com irônico distanciamento e um cinismo de fundo, valores e atitudes que atualmente coexistem e colidem no ambiente social brasileiro. Muitos dos contos emitem uma voz anônima que se identifica com um grupo e esquematicamente se opõe a outros: de um lado, "a gente que é do Brasil", "a gente que é homens de bem", "nós é que votamos no Fernando Collor", "gente bonita, do jeito que a gente gosta", "[e]u sou bom porque eu sou brasileiro", "a nossa pátria, que é o Brasil"; de outro, "esse pessoal do [sic] direitos humanos", "classe baixa-alta", "esses filhinho [sic] de papai", "meia dúzia de pobres pretos vagabundos", "esse pessoal de esquerda".

Em alguns textos, é adotado o ponto de vista dos que querem a todo custo se distinguir da ralé:

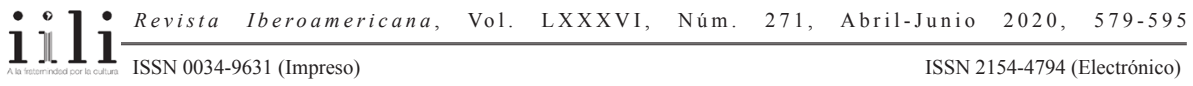


Você é diferente. Você não é igual. [...] Essa gente se esfregando pelas ruas, suada, feia, sem dente, vendendo coisa barata, comprando coisa que não devia ser vendida, bebendo pinga, berrando palavrão, fazendo farofa, comendo espetinho de camarão, dançando música de bundinha, berrando o hino do Vasco, não, você não é assim. (“Amando" 45)

Contos como "Para ser sincero" " "Nós somos bons" também adotam a perspectiva de uma classe suficientemente privilegiada para se sentir ameaçada pela aproximação das "novas classes", setores marginalizados que na última década e meia puderam experimentar alguma melhora em sua situação social devido a políticas econômicas, programas de transferência de renda e de acesso à educação universitária (Condé e Fonseca 166). Em "Nós somos bons", o narrador na primeira pessoa do plural traça um apanhado da trajetória política de uma classe média que apoiou o golpe militar; elegeu Collor "que não fazia o Brasil dar vexame em compromissos internacionais" (28); recusou o candidato presidencial Lula por ser "um nordestino ignorante que não sabia falar inglês" (27); optou por "um governo capaz de acabar com a inflação [...] para podermos comprar um carro a nível de primeiro mundo" (28) e, por fim, reavaliou Lula, que "tinha ficado simpático, sorridente, vestindo ternos mais alinhados" e que não iria aumentar "nossos impostos demais para melhorar as escolas e os hospitais que atendem essa gente nordestina preta, pobre e sem educação" (29). Esse "nós", "os bons", que alternadamente expõe e recalca seus preconceitos de classe, busca sempre preservar a própria pele, mas cinicamente apresenta a fala doce de quem se mostra preocupado com o conjunto da nação: "ainda vamos desenvolver o país, gerando empregos, gerando renda" (29). O tom se torna mais agressivo em "Para ser sincero": um telefonema de telemarketing em prol de uma campanha para crianças com câncer dispara a cólera de um narrador contra "gente meio pobre":

[...] uma gente de uma classe baixa-alta, dirigindo uns carros pagos em trocentas prestações, uma gente meio gorda com umas espinhas e umas perebas na cara e na bunda, umas crianças balofas comendo pastel, comendo qualquer coisa [...] e uns caras mais pobres ainda, da classe baixa-média, esses que são meios urubus, que ficam com os restos, reciclando lata de alumínio [...] e eu me sentindo meio incomodado, meio que com um vazio existencial profundo. (18-19)

A indisposição com os rumos recentes da economia e política no Brasil aparece já no primeiro texto do livro, "Deus é bom no. 8", que recorre a uma alegoria para traçar o percurso de um político, referido como Jesus, "que nasceu num barraco bem pobrinho, num lugar bem pobrinho" (7), e que, graças ao carisma e a acordos políticos, abandonou seu radicalismo e foi aceito pelos "vendilhões do templo" "que tinham lá suas boas relações com o mercado internacional de dinheiro" (8). O resultado é que

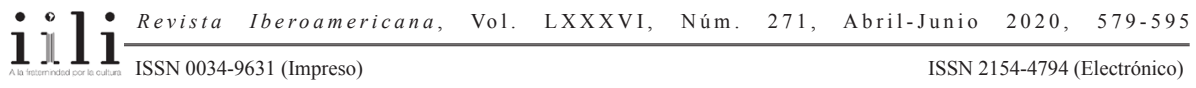


"os que mais precisam viraram classe média baixa-alta cheia de autoestima" (8) que "está sob controle comprando iogurte e batata chips" (9). Para o narrador deste conto, a ascensão social das classes menos favorecidas não passa de uma farsa, controlada de cima, em favor de um modelo econômico que, inspirado pela "compaixão pelos oprimidos, pelos desvalidos, pelos desdentados, pelos explorados, pelos sem-terra" (7) não teria feito mais do que integrar segmentos mais pobres aos valores condenáveis da sociedade de consumo. Nesse processo, segundo a perspectiva desse narrador, os beneficiados não questionam a lógica da perversidade econômica e, portanto, as engrenagens do sistema permanecem intactas: "e se Jesus por acaso vier de novo com esse papo de amor ao próximo, a própria classe baixa-alta vai botar Jesus na cruz. A classe baixa-alta adora crucificar os outros" (9). A ausência de projeto político desses recém-cooptados pelo sistema explicaria o argumento do narrador de "Para ser sincero", que, em sua indignação contra o pedido de contribuição para as crianças com câncer, desabafa: "Eu disse para a mulher das crianças que estavam com câncer que ela não devia pedir esmola a esse pessoal da classe média-média. Eu disse que ela devia era convencer a classe baixa-alta a fazer uma revolução comunista e obrigar a indústria de produzir leite a salvar as crianças com câncer” (20).

Mas não há revolução comunista no horizonte do país redemocratizado de $O$ Brasil é bom. Quando a "classe baixa-alta" toma a voz, nada surge de redentor. Vale notar a esse respeito, retomando o comentário de Süssekind antes mencionado, que os contos de Sant'Anna não mimetizam apenas torrentes discursivas da classe média tradicional, mas perfazem um múltiplo e tensionado registro verbal-ideológico da sociedade brasileira atual. $\mathrm{O}$ autor sempre se destacou pelo refinamento com que constrói, em contraponto, potentes fluxos verbais para dar feitio a suas personagens, não apenas àquelas que refletem o mundo letrado e burguês, mas também àquelas das classes sociais mais baixas, na esteira de Graciliano Ramos, Dalton Trevisan e Rubem Fonseca. Já em O paraíso é bem bacana, romance de 2006, o protagonista Mané é formatado essencialmente por um cruzamento vertiginoso de discursos. Garoto pobre e inculto, talentoso jogador de futebol, Mané é contratado por um time da Alemanha, país onde ingenuamente se envolve com terroristas islâmicos. No texto do romance de Sant'Anna, o leitor só escuta a voz de Mané quando a personagem está delirante, depois de ser vitimada pela explosão de uma bomba que carregava consigo. O que se conhece de Mané são seus circulares devaneios na cama de hospital, e mais os relatos fragmentados de testemunhas que se manifestam diretamente em primeira pessoa ou se cruzam na voz do narrador em terceira pessoa. Em O Brasil é bom, esse mesmo vórtice discursivo está na prosa de cada um dos vinte e três contos e constitui o dispositivo literário que dá unidade ao conjunto. No conto "O futuro vai ser bom", cuja sintaxe parece querer representar a linguagem do cidadão pouco escolarizado, o tom é de passiva aceitação da ordem social e de discursos alheios, saturados de um otimismo fácil: 
Vai, vai ser, sim, um futuro maravilhoso para o Brasil e para você, brasileiro, que mesmo nos momentos mais difíceis jamais deixou de acreditar, nunca desistiu de alcançar seus objetivo. [...] No futuro, você, brasileiros e brasileiras, tem que continuar consumindo produtos, comprando carro e iogurte daqueles que faz as senhoras ir no banheiro. (15)

Nada transcende nesse mundo de frases feitas e ideias prontas que estruturam muitos dos textos do livro. Não à toa, o título de um dos contos-“Comentários na rede sobre tudo o que está acontecendo por aí"-estabelece uma importante referência às redes sociais na Internet, a ágora eletrônica da contemporaneidade, onde cidadãos dos mais variados extratos sociais e perfis ideológicos facilmente podem emitir (ou reproduzir) opiniões, sem peias ou maiores cuidados quanto a procedimentos de checagem, ponderação e elaboração. O conto diz muito de aspectos toscos dessa cultura online, feita na base de retalhos de informação circulando em um espaço virtual hiperdemocrático que, paradoxalmente, em nada tem contribuído para a superação de posicionamentos fascistas:

\begin{abstract}
Aí, quando vem um bandido e pega o seu carro no farol e dá um tiro na sua cara, você que é um cidadão de bem, com a sua família, o que é que acontece? Vem o direitos humanos e protege os bandidos e quer que a gente que é homens de bem, que não temos direitos humanos nenhum, fique quieto vendo os estupradores todos levando boa vida lá na cadeia, comendo comida que a gente paga e até levando mulher lá prá dento, prá fazer sexo. (“Comentário” 22)
\end{abstract}

Segundo esse narrador, "o direitos humanos" consiste em uma entidade, espécie de instituição que "vem aqui se meter no Brasil" (21). Ele rejeita os direitos humanos por serem uma "mania" alienígena, longe de compreendê-los como eixo de um regime democrático e, portanto, como desejável princípio organizador da sociedade a que pertence. Esse narrador nacionalista que é "igual o velho lobo Zagallo, totalmente verde e amarelo" (23) faz eco ao narrador de "Amor à pátria" que, repetindo chavões a respeito de futebol, transfere aos comentários políticos a mesma ligeireza descompromissada que dedica ao esporte: "Então, agora tem que ter coerência. Porque uma coisa que é boa pra uma pessoa talvez não seje [sic] boa pra outra. Igual ditadura. Tem gente que fala que é ruim e tem gente que acha que é boa, a ditadura. Na ditadura, o Brasil não tinha a Copa de 70? Não tinha o Pelé? Então, a ditadura era boa a nível de futebol" (41).

A avaliação superficial e seletiva da ditadura, capaz de ver seu "lado bom" e tolerar suas atrocidades, reproduz, décadas depois, o uso ideológico que à época o próprio regime civil-militar fez dos êxitos internacionais da seleção brasileira de futebol em 1970, justamente no período de mais violenta repressão política no país. "O importante é o resultado, igual a ditadura", prossegue o narrador. "Eles podiam prender esse pessoal de esquerda, sei lá, mas aí o Brasil ganhou o tri” (42). Essa

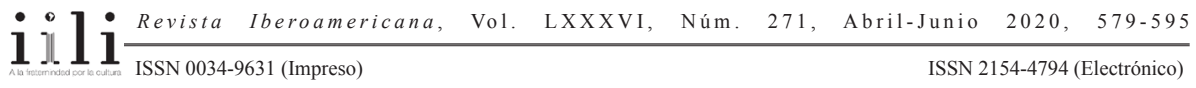


espécie de Realpolitik do cidadão comum, pronto a aceitar a barbárie em troca de trivialidades, indica um dos aspectos mais trágicos e persistentes da sociedade brasileira: a fluidez com que se manipulam a bel-prazer princípios éticos e códigos de conduta humanitários, constantemente desrespeitados, mas nunca assumidamente abolidos. Essa indefinição não é algo totalmente novo, nem na sociedade nem na literatura brasileiras. Roberto Schwarz, em seu conhecido estudo sobre Memórias póstumas de Brás Cubas, aponta como o narrador de Machado de Assis mimetiza a volubilidade de uma elite que, em defesa de seus interesses bem concretos, busca acomodar perspectivas conflitantes com o sistema liberal-burguês (Schwarz, Um mestre 129). Mas, no caso de "Comentários na rede sobre tudo o que está acontecendo por aí" e de vários outros textos de $O$ Brasil é bom, a focalização não se faz pelos olhos da elite, aquele 0,3\% do topo da pirâmide social que concentra 21,7\% da riqueza do país ("Relatório" 11). Tampouco se trata da perspectiva do malandro de Manuel Antônio de Almeida, que aspira sinuosamente integrar-se ao polo da ordem social, sem estabelecer a crítica dos valores que o marginalizaram em primeiro lugar (Cândido, "Dialética" 78-79). Nem ainda da postura não conciliadora dos marginalizados representados na literatura e no cinema contemporâneos, expondo a impossibilidade de pacto entre "o pequeno círculo dos donos do poder e o crescente universo dos excluídos" (Rocha 174). O que se lê na ficção de Sant'Anna é a atitude do cidadão mediano, o "homem de bem", que se solidariza com um sistema de valores que só tangencialmente o beneficia, mas que parece seduzi-lo incessantemente com a promessa de locupletação. Individualista, ressentido com sua posição social periclitante (insuficiente para atender seus grandes sonhos de consumo e ameaçada pela constante instabilidade econômica), o "homem de bem" da classe média e da arraia-miúda encontra a sua verdade em meio a uma verborragia obscurantista: "se vocêé forte, bata. Se você é fraco, apanhe" ("Use sempre" 25). Tal máxima, aplicada de maneira menos ou mais explícita, só pode produzir uma sociedade cindida, em que a solidão e o desamparo são a norma:

Você está só porque as pessoas do lugar onde você trabalha estão correndo atrás do dinheiro, mantendo as aparências de uma amizade falsa por você, porque elas não te conhecem direito mesmo, porque elas não estão nem um pouco interessadas em conhecer você de verdade, porque conhecer você de verdade e manter uma amizade de verdade com você as obrigaria a tomar uma posição verdadeira a favor de você, caso as pessoas que pagam o salário delas, o seu salário, resolvam se voltar contra você, ameaçando você com a perda do seu emprego [...] e, no dia em que você perder o seu emprego as pessoas do lugar onde você trabalha vão sorrir para você, vão desejar boa sorte a você, mas vão demonstrar para as pessoas que pagam o salário delas, que pagavam o seu salário, que elas não estão com você para o que der e vier, que elas não são tão próximas assim de você, que elas gostam muito mais das pessoas que pagam o salário delas, o dinheiro delas, do que de você. ("Só" 56-57) 
Evidentemente, a dissimulada agressividade entre iguais do mundo corporativo não é o único efeito perverso dessa sociedade em que o dinheiro é "a coisa mais importante que existe". Quando no jogo entre "forte" e "fraco" entra em cena o outro, a diferença entre "bata" e "apanhe" torna-se mais violenta: "[s]e eles, os moleques, têm idade para roubar, para estuprar, para vender maconha, também têm idade para levar umas porradas, para pegar uma cadeia" ("Use sempre camisinha" 25).

No livro de Sant'Anna, a expressão mais aguda da brutalidade social-assim como o ápice do ventriloquismo do narrador-encontra-se no conto "Lodaçal." São 51 páginas de uma prosa em ostinato, onde imagens vertiginosamente se repetem e sofrem variações, num jorro discursivo essencialmente paratático que faz o inventário sinistro dos lugares que o pobre e o miserável ocupam numa sociedade excludente e opressiva. O conto foi publicado originalmente em Essa história está diferente-dez contos para canções de Chico Buarque, lançado em 2010. Na apresentação de Ronaldo Bressane a esse volume, explica-se que "neste livro, dez escritores recriaram o cancioneiro do compositor carioca, com liberdade total para reinventar em prosa a canção que escolhessem" (Bressane 9).

André Sant'Anna inspirou-se na letra da canção "Brejo da Cruz", do LP Chico Buarque, gravado em 1984, no ocaso do regime civil-militar e em pleno processo do movimento "Diretas Já". Ao lado de canções que anunciavam a superação do trauma histórico e a instituição de um novo momento nacional ("Pelas tabelas" e "Vai passar"), "Brejo da Cruz" acusa, ao contrário, um quadro de crise, herança dos 21 anos de ditadura: o aprofundamento da iniquidade social e da miséria, o agravamento das condições de vida no campo, o consequente incremento dos fluxos migratórios e a deterioração da qualidade de vida nos centros urbanos (Luna e Klein 91). A literatura, a música e o cinema brasileiros produzidos àquela época se ocuparam da situação alarmante dos marginalizados pelo "milagre econômico" que, promovido pelo governo militar entre 1968 e 1973, só fez piorar os índices de distribuição de renda no país. Em 1981, O homem que virou suco, filme de João Batista de Andrade (que já havia rodado o documentário Migrantes, em 1973) abordava a questão do migrante e da sua resistência para não ser oprimido pelo imperativo da produtividade capitalista. O mesmo Andrade havia focalizado no documentário A escola de 40 mil ruas (1975) um problema de longa data no Brasil mas que se agravou com o crescimento urbano descontrolado a partir da década de 1960: a questão dos menores em situação de rua-perseguidos brutalmente por esquadrões da morte-e das instituições correcionais da criança e jovem infratores. Em 1977, José Louzeiro publicou seu romance-reportagem Infância dos mortos, baseado na "Operação Camanducaia", quando cerca de cem menores infratores foram levados do Departamento Estadual de Investigações Criminais (DEIC) de São Paulo a Minas Gerais, onde foram espancados e abandonados, nus, numa ribanceira. A discussão do tema ganhou fôlego com a abertura política já que, ao apontar as brechas do projeto

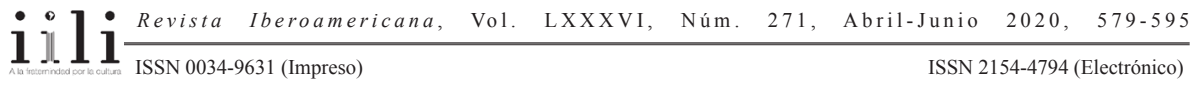


econômico civil-militar e as práticas abusivas de instituições controladas pelo Estado, feria a susceptibilidade do regime. Em 1980, Hector Babenco inspira-se na obra de Louzeiro e dirige o filme Pixote, a lei do mais fraco. Naquele momento em que o país real se redescobria, Babenco manteve o gênero semi-documental de Infância dos mortos, fazendo preceder a narrativa ficcional cinematográfica por uma abertura de caráter referencial. Nela, o próprio diretor explica, enquanto a câmera oferece uma panorâmica de um bairro favelado, a situação dos 28 milhões de crianças que viviam em condições abaixo das normas dos direitos internacionais das Nações Unidas. Àquela altura, a pobreza começava a interessar a classe média que frequentava as salas de cinema e que sentia os efeitos da crescente violência urbana. Em 1982, é publicado A queda para o alto, em que Anderson Herzer, identidade que a jovem Sandra Mara Herzer escolheu assumir, reúne seus poemas e narra sua trajetória de criança de rua e suas várias passagens pela FEBEM, onde o menor ganha "uma cicatriz que lhe sangra todas as noites, dentro de uma cela, num 'pau-de-arara', numa tortura que antes de lhe ferir o corpo, fere primeiramente seu coração já magoado, já tão espezinhado, tão pequeno" (Herzer 138).

O próprio Chico Buarque compôs, antes de "Brejo da Cruz", duas canções sobre o tema dos menores infratores: "Pivete" (1978) e "Meu guri" (1981). Enquanto na primeira as ações do infrator são enumeradas num tom quase brejeiro, livres de qualquer sanção, em "Meu guri" esboça-se a trajetória de vida do jovem infrator que, depois de preso, termina no mato, morto. A canção finaliza num corte irônico ("ele disse que chegava lá"), que estabelece um comentário sobre a trágica previsibilidade do destino da criança pobre no Brasil. "Brejo da Cruz", por sua vez, também se ocupa da infância miserável, mas evidencia outros desdobramentos. $\mathrm{Na}$ abertura da canção, aparece a fome como raiz do problema: "A novidade / que tem no Brejo da Cruz / é a criançada / se alimentar de luz" (Buarque).

De um brejo distante-potencialmente localizado em qualquer ponto periférico do país-os miseráveis e famintos se desmaterializam, "cruzam os céus do Brasil" e chegam às rodoviárias das metrópoles, assumindo "formas mil". No cenário urbano, os despossuídos avizinham-se então dos grupos socialmente hegemônicos, passando a desempenhar papéis facilmente reconhecíveis de um lumpesinato quase folclórico: "muito sanfoneiro cego", os que "vendem fumo", os que "viram jesus", os que "passeiam nus", os que "dançam maracatus". Em comparação com outras composições de Buarque, "Brejo da Cruz" amplia o ângulo da fotografia social e compõe um retrato mais variado das camadas populares. Evitando o sentimento paternalista e contemporizador que revela queda emocional pelo pitoresco da pobreza ("Gente humilde") ou pela redenção revolucionária ("Construção"), a letra de "Brejo da cruz" flagra a estrutura social de maneira mais complexa, plural e cínica. Complicando a categoria dos marginalizados e subalternos, surge um novo elemento que a um só tempo nega e testemunha a presença

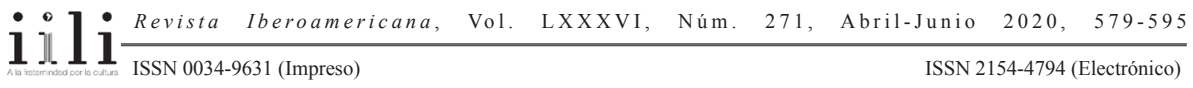


da miséria no centro do sistema: são os "milhões desses seres que se disfarçam tão bem". Nesse segmento social dos "que se disfarçam", entram aqueles que, apesar de terem logrado escalar ligeiramente a pirâmide social, mantêm-se na base do sistema, figurando como "jardineiros, guardas-noturnos, bombeiros, babás, faxineiros, bilheteiras, baleiros, garçons". Esses representantes do precariado, serviçais das classes mais abastadas, tentam, segundo a letra da canção, negar sua origem e sua situação de penúria social, dificultando qualquer solidariedade de classe num processo de salve-se quem puder, em que o remendado tenta não se lembrar de que já foi, um dia, roto: "já nem se lembram / que existe um brejo da cruz / que eram crianças / e que comiam luz” (Buarque).

Dessa forma, o texto de "Brejo da Cruz" refrata a representação de classe em matizes e contradições, procedimento que o conto de Sant'Anna retoma e amplifica, sem vislumbrar, também nisso conforme à letra da canção, qualquer solução. Os personagens do conto de Sant'Anna, Chiquinho e Toninho, são duas crianças miseráveis do Brejo da Cruz. Mas, no decorrer da narrativa, metamorfoseiam-se, como na canção que a inspirou, em "formas mil". Desempenham uma miríade de papéis e reaparecem, incessante e ciclicamente, sob essas máscaras numa profusão de situações e numa colagem de discursos que se juntam em arranjos sempre novos e sempre reversíveis. Chiquinho e Toninho serão ao longo da narrativa taxista, bilheteiro, ator "bichinha", assaltante, calouro de programa de auditório, subgerente, crente, policial, pedreiro, empregado de supermercado, atendente de padaria, pinguço, retirante favelado, criança abandonada na calçada, instrumentista num coreto do interior, cortador de cana escravizado.

O resultado é uma representação ficcional de uma sociedade, a brasileira, que oferece privilégios para uns, subtrai direitos e oportunidades de outros e coopta, pelas promessas de ascensão e sob o custo da alienação e da violência, uma parcela dos remediados sociais:

O Chiquinho também, chegou longe e estava no caminho certo, já pronto para começar a superar obstáculos, para alcançar todos os seus objetivos. Nascer onde Chiquinho nasceu, e chegar até aqui, onde o Chiquinho está agora, nesta enorme avenida, andando com um grupo de subgerentes [...]. Certo, o terno é meio barato, meio mal caído, e brilhantina no cabelo e o Chiquinho mora numa pensão de quinta no Catete, e o Chiquinho é meio burro, meio idiota, e o Chiquinho tem todas essas qualidades necessárias, fundamentais, para ser um subgerente [...] a gente não pode esquecer que o Chiquinho já foi até escravo, que o Chiquinho deixou de ser analfabeto só aos quinze anos, com muito esforço, superando todos os obstáculos para chegar até aqui, na avenida enorme, com um sapato com a sola pesada, falando da bunda de uma secretária com um grupo muito divertido de subgerentes, indo comer no restaurante por quilo, pisando no pé do Chiquinho como se o Chiquinho nem existisse, com aquela cara idiota de criança sem colesterol que acha que vai subir na vida só porque anda de terno [...]. ("Lodaçal” 110-11) 
No trecho, Chiquinho é ao mesmo tempo o subgerente que aposta na ascensão social e o menino de rua "sem colesterol" sentado na calçada, cujo pé o subgerente pisa como se ele "nem existisse". Essa dança das cadeiras entre os personagens sugere tanto a reversibilidade dos papéis sociais-aquele que bate poderia ser aquele que apanha e vice-versa-, como a falta de empatia que resulta num tecido social esgarçado. Para o leitor, a rotatividade de pontos de vista também dificulta a identificação com os personagens, relativizando os julgamentos e rarefazendo as verdades do texto.

Os primeiros parágrafos do conto dão a medida de uma prosa que, transmutando-se à medida que repisa certas imagens, temas e situações, não fornece chão para nenhuma certeza. A tentativa de se definir o local da narrativa é exemplar desse processo de esvaziamento que se repete insistentemente ao longo do texto: "[...] o Brejo da Cruz é uma cidade, é uma aldeia, é um lodaçal, é umas quatro/cinco casas, é nada, é um brejo em cima de um campo de futebol submerso pelo lodaçal com uma cruz bem no meio do círculo central que nunca fora traçado no campo de terra seca rachada [...]" (69).

A sequência soma elementos para paradoxalmente desconstruir o todo. O resultado é um texto ao mesmo tempo enérgico e sem rumo, que compõe uma representação desfibrada que mimetiza uma alucinação: tudo cabe, tudo significa, mas nenhum sentido se fixa, nada parece ter substância:

[...] o Toninho correndo com a bola que o Chiquinho também não sabia o que era, televisões de rodoviária, tapes de jogos de futebol de televisão de rodoviária, jogos de futebol de tempo nenhum, abolição do tempo, rodoviária, lugar nenhum e, em volta das pessoas que não viam o Chiquinho, havia muita luz, muito som, som sem significado [...]. (74-75)

Esse brejo-nem campo de futebol, nem altar; centro sem centro-localiza-se ao lado de plantações de maconha "sem valor comercial" e não oferece outra fonte de alimentação senão sapos. Mas Toninho e Chiquinho não aguentam comer os enjoativos sapos, então não comem nada. Famintos, possuindo apenas um fósforo, acendem um baseado numa noite estrelada. Portanto, os descompassos da narrativa, a implosão da trama ficcional, a miríade de personalidades de Chiquinho e Toninho ao logo do texto, tudo pode ser entendido como uma viagem delirante de dois esfomeados que fumam maconha. Se assim compreedidas, as incompatíveis figurações de Chiquinhos e Toninhos, que dão à narrativa seu caráter de documento social, paradoxalmente não passariam de uma longa alucinação. A aberrantemente injusta realidade brasileira só cabe num fluxo fantasmagórico: na base das "alternativas" de vida, estão sempre o mesmo Chiquinho e o mesmo Toninho, os miseráveis do Brejo da Cruz.

Também a interpenetração polifônica de vozes sociais, ao mesmo tempo que faz um registro factual, coopera para a atmosfera surreal: ouvem-se as palavras, argumentos, jargões e clichês dos profissionais da mídia e da moda, do político, do médico, do

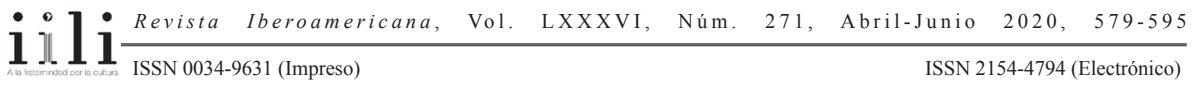


psicólogo, do intelectual, do jovem "ilustrado," do leitor de Carlos Castañeda, da celebridade midiática, do ladrão, do evangélico, do homossexual, dos executivos, da polícia, do trabalhador, do preguiçoso, do estuprador, da secretária, do adolescente fissurado em sexo, do humilde que venceu na vida, do reacionário, do chauvinista. Chiquinho, Toninho e alguns outros personagens que aparecem na narrativa são, em síntese, porta-vozes de discursos em choque.

A orquestração desses discursos todos, convulsiva e contrapontisticamente apresentados, evita a redução essencialista. O outro retratado no conto nunca se deixa prender na armadilha da previsibilidade, que o faria refém dos discursos automatizados -mal ou bem intencionados-que buscam descrevê-lo e interpretá-lo de fora e de longe. Em "Lodaçal", o sofrimento não é homogeneizado e os sujeitos, cada um vulnerável ao seu modo, não formam um grupo, não pertencem a uma única categoria. Dada a fragmentação das consciências e das experiências, nenhuma coesão social se efetiva, nenhuma consciência e solidariedade de classe parece possível, e as alianças se dão com as forças de opressão:

O Toninho, na padaria, falando para o cara, acho que o Chiquinho mesmo, atrás do balcão [...] que ninguém gosta de ninguém, que esse negócio de gostar é coisa que esse pessoal de esquerda inventou, que no supermercado onde ele trabalha, o Toninho, aparece os cara esquerdo dizendo que a gente tem que ser unido pra enfrentar os dono do supermercado, como se os dono do supermercado fosse inimigo da gente, mas são os dono do supermercado é que dão o emprego pra gente, que a gente, eles, ele, o Toninho inclusive, principalmente, é que é preguiçoso [...]. (86)

Como elo social entre os despossuídos parecem restar apenas os valores, desejos e modelos propostos pela sociedade de consumo e as promessas de ascensão que movem a engrenagem capitalista, impulsionada pelos meios de comunicação. A identificação coletiva se dá exclusivamente de forma mediatizada, em relação à celebridade "que venceu graças ao seu esforço formidável" e que acena da janela de um hotel para uma multidão embasbacada:

O Toninho e o Chiquinho tentando ver ela lá em cima, no meio da multidão gritando "eu te amo, eu te amo, eu te amo, eu te amo", sem saber que era ela, tão amada lá em cima $[. .$.$] e lutou muito até chegar aqui depois de batalhar muito pela carreira, minha$ carreira é minha vida [...] e eu amo muito todos vocês, vocês são tudo na minha vida, o Toninho e o Chiquinho, lá embaixo, olhando pra cima, sem saber direito por que estavam gritando eu te amo, sinceramente. (91-93)

Nessa "sociedade do espetáculo" de que fala Guy Debord, em que a "realidade surge no espetáculo" (16), não resta nem mesmo a solidariedade pela compaixão. A reação costumeira frente ao destituído-o sentimentalismo piedoso-é escancarada em

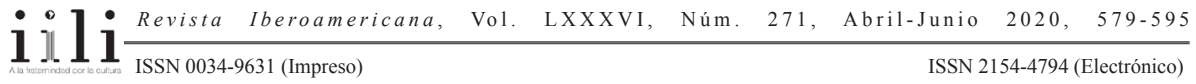


sua ineficácia e na arbitrariedade de seu exercício. Numa certa altura, o narrador ironiza os sentimentos contraditórios que uma jovem passante manifesta em relação a duas crianças de rua: "tem mais pena do Toninho, que [...] é menorzinho, mais bonitinho e mais carentezinho do que o Chiquinho, que já está meio grandinho e, daqui a pouco, já vai começar a merecer tomar umas porradas, que é para aprender" (85).

Para o narrador do conto, nem mesmo o texto literário e seus efeitos, potencialmente piegas, merecem confiança. No cenário de carência absoluta, onde "tudo é nada", a noite é de lua e estrelas, de modo que fome, maconha e a emoção suscitada pela paisagem resultam num "troço" inexprimível dentro daqueles dois meninos. O narrador então estabelece uma equação profundamente irônica e desconcertante entre miséria e subjetividade: "Tudo, no nada, é vida interior". E lança uma pergunta: "Poesia isso?" Mais que uma tirada de humor negro, a pergunta toca no cerne da questão ética da representação do outro pela literatura: como falar de uma humanidade que resiste em meio à desolação? Que poesia é essa que fala do miserável? Essa poesia estaria a serviço de uma subjetividade-a do marginalizado-que não é menos complexa por ser carente e vulnerável? É possível gerar literatura a partir da pobreza sem desviar a atenção para as seduções da linguagem literária? Sem pieguice? Sem dissolver o incômodo e anular a provocação? Ou a provocação estaria justamente em flagrar a poesia onde ela parece mais improvável? ${ }^{2}$

No prefácio da antologia de ensaios Os pobres na literatura brasileira, de 1983, Schwarz escrevia que "a situação da literatura diante da pobreza é uma questão estética radical" (8). Dizia também que "poetas sabem muito sobre muita coisa, inclusive, por exemplo, sobre a pobreza" (7). No final daquela mesma década, Antônio Cândido, ao tratar do que chamou de "realismo feroz" da literatura brasileira, afirmou que o escritor de então queria "apagar as distâncias sociais identificando-se com a matéria popular" (“A nova narrativa” 213). Essa aproximação empática do escritor proporá sempre uma questão delicada, especialmente em um país em que a literatura é produzida e consumida por um círculo social restrito. Não é outro o teor da reflexão de Marisa Lajolo em texto da mesma década de 1980. Afirma Lajolo que "o discurso do pobre presente em nossa literatura pode constituir uma última forma de expropriação, na medida em que não é o pobre o sujeito desse discurso sobre ele" (104). Semelhante observação faz Regina Dalcastagnè quando, apoiada em dados reveladores, trata da rara presença de negros entre os escritores brasileiros: "não há, no campo literário brasileiro, uma pluralidade de perspectivas sociais" (89).

Se a representação literária das condições de vulnerabilidade e opressão em larga escala se mantém ainda hoje monopólio de quem, empaticamente, vê a situação de fora, então mantém-se também o risco de a obra literária revelar mais do retratante do que

\footnotetext{
A respeito do olhar piedoso em relação à pobreza na literatura brasileira, ver Chiara, 227-37.
} 
do retratado. Se assim é, a solução ficcional de André Sant'Anna em "Lodaçal" acerta ao escolher o caminho da radical desestabilização das verdades do texto, implodindo a voz do narrador e a ilusão de uma perspectiva única que dê conta do real. Além disso, no conjunto do livro, Sant'Anna não deixa de inscrever, por meio de textos auto-ficcionais, o locus de onde capta e analisa a realidade brasileira. Nos últimos quatro contos de $O$ Brasil é bom, o narrador-personagem constrói uma mascarada, identificando-se como uma série de figuras históricas, como George Harrison, Tostão, Rivelino e Sócrates. Em meio a esse jogo, lança elementos que associam esse narradorpersonagem com o autor, em passagens como "O George Harrison nunca pensou em ser escritor, pois o pai dele, do André, é um escritor" ("História da Alemanha" 176) e "[e]screvi até um romance que é a história de um jogador de futebol ubatubano que vai jogar no Herta Berlim" (189). Como em outros contos do livro, nos quatro textos finais ("História da revolução", "História do rock", "História do futebol" e "História da Alemanha") as metamorfoses são o fio condutor, desta vez para contar a bio-ficção de André Sant'Anna e perfazer, simultaneamente, o arco histórico do início do golpe militar até os dias de hoje:

O mundo onde George Harrison estava começando a ficar cabeludo, onde o George Harrison estava começando a fumar uns baseados e a tocar iê-iê-iê, onde George Harrison foi gerado e nasceu, em 1964, era um mundo muito doido. Deve ser por isso que sou doido. [...]

O George nasceu para ser um filho da revolução, um menino de 64, uma criança de sorte, que cresceria em um país novo, com um futuro sensacional pela frente, farol da humanidade, gigante a despertar, essas porra. ("A história da revolução" 125)

A ironia da expressão "criança de sorte" é evidente, mas a trajetória de "George Harrison" não se confunde com a dos miseráveis de "Lodaçal". Certo é que a história pessoal desse escritor-narrador-personagem do final do livro se articula com a história recente do Brasil, mas pelas condições de vida apresentadas nos textos autoficcionais, estamos desta vez do lado daqueles que nem foram perseguidos como inimigos do regime, nem foram as vítimas desamparadas das políticas econômicas e do sistema social excludente. Por sua formação familiar e outras diversas circunstância favoráveis, o escritor-narrador-personagem não compartilha nem dos gostos de uma burguesia que só pensa em dinheiro, nem das teses de "uns cara à tarde na televisão pedindo que no Brasil tenha pena de morte" ("História da Alemanha" 189). Por outro lado, não pode aceitar a falência do país em garantir qualidade de vida e uma convivência comunitária mais digna e menos violenta. Tampouco se deixa seduzir pelos indícios de maior inclusão social dos pobres na vida econômica do país. Compreende-se melhor, assim, seu ceticismo e desolação com um Brasil que "não vai rolar", um Brasil que mesmo com a redemocratização não consegue ser "[o] Brasil afro-índio-europeu do Mautner,

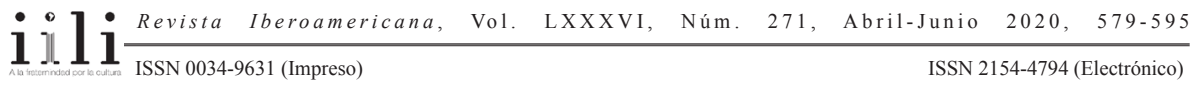


o Brasil Frátria que o Caetano sugeriu, o Brasil onde haveria a Revolução Eztétyka do Glauber Rocha” (188). Porque, sendo "a sexta economia do mundo", o Brasil:

[...] é cheio de crianças pedindo dinheiro nas ruas, e fica a impressão de que o Brasil é grande-merda só porque não deve mais dinheiro ao FMI e todo mundo tem carro e sai por aí, por lá, atropelando as pessoas, provocando uns acidentes cheios de sangue, construindo uns hotéis/resorts cafonas, emporcalhando tudo onde antes havia aqueles litorais do Dorival Caymmi e do Ari Barroso. (188)

Ao final, George Harrison-André Sant'Anna, que teve a oportunidade de conhecer outra realidade, pode emitir uma "blasfêmia absoluta" "no país da Copa do Mundo, dos Jogos Olímpicos e das instituições de espancar crianças", uma blasfêmia que derruba, nas linhas finais, o próprio título da obra: não, o Brasil não é bom, "a Alemanha é muito melhor do que o Brasil" (190). Que deva existir uma realidade melhor que a do Brasil bem o devem saber-ou provavelmente não-os Chiquinhos e Toninhos que ao final de "Lodaçal" são mortos com tiros na nuca:

[...] o Chiquinho, policial honesto, explica que foi melhor assim, que aquela gente naquela aldeia com aquela cruz no meio do lodaçal tinha uma vida miserável que não era nem vida, que ele, o Chiquinho, posso falar porque eu vim de lá, eu era aqueles dois ali e, vou te falar, eu preferia que alguém tivesse feito pra mim o que eu fiz pra eles, nem doeu e acabou logo. ("Lodaçal” 120)

A literatura de André Sant'Anna indica, com desesperançado amargor, que o fim oficial da ditadura não se traduziu na conquista de um estado de pleno direito e de uma sociedade mais justa, mais democrática e menos cruel. Ao representar as muitas formas pelas quais o Brasil "não está rolando", os contos de O Brasil é bom trazem à superfície os discursos e práticas mais obscurantistas, inconsistentes e violentos que se infiltraram na mentalidade e na atitude dos brasileiros. Lembra-nos de que Chiquinhos e Toninhos-pobres, periféricos, marginalizados-continuam a ser torturados e/ou executados nas ruas (e nos presídios, aldeias indígenas, acampamentos de sem-terra...). O que está sobrando nesse quadro social não são, seguramente, os direitos humanos. 


\section{OBRAS CITADAS}

A escola de 40 mil ruas. João Batista de Andrade, dir. Globo, 1975.

"Audiência pública". Comissão de Direitos Humanos e Minorias da Câmara dos Deputados, reunião $\mathrm{n}^{\mathrm{o}}$ : 1758/15. 16 sept. 2015. <www2.camara.leg.br/ atividade-legislativa/comissoes/comissoes-permanentes/cdhm/documentos/notastaquigraficas/16-09-2015-audiencia-publica/view>. 6 fev. 2017.

Bressane, Ronaldo. "Apresentação." Essa história está diferente-dez contos para canções de Chico Buarque. Ronaldo Bressane, org. São Paulo: Companhia das Letras, 2010. 8-9.

Cândido, Antônio. "Dialética da malandragem". O discurso e a cidade. São Paulo: Duas Cidades, 1993. 67-89.

"A nova narrativa". A educação pela noite e outros ensaios. São Paulo: Ática, 1987. 199-215.

Chauí, Marilena. "Democracia e sociedade totalitária". Revista comunicação \& informação 15/2 (2012): 149-61.

Chiara, Ana Cristina Rezende. “'Gente quer luzir': figurações de 'um outro-real, um ultrarreal' no enfoque da pobreza”. Alea 13/2 (2011): 227-37.

Chico Buarque. Chico Buarque. Barclay, 1984.

Condé, Eduardo Salomão, e Francisco Fonseca. "A macrodinâmica social brasileira: mudanças, continuidades e desafios". Dados 58/1 (2015): 151-85.

Dalcastagnè, Regina. "Entre silêncios e estereótipos: relações raciais na literatura brasileira contemporânea". Estudos de Literatura Brasileira Contemporânea 31 (2008): 87-110.

Debord, Guy. A sociedade do espetáculo. 1967. Rio de Janeiro: Contraponto, 1997.

Dreifuss, René Armand, e Otávio Soares Dulci. "As forças armadas e a política". Sociedade política no Brasil pós-64. Bernardo Sorj e Maria Hermínia Tavares de Almeida, orgs. Rio de Janeiro: Centro Edelstein de Pesquisas Sociais, 2008. 132-81.

Feltran, Gabriel. "A disputa política nas periferias". Entrevista por Marina Amaral. Agência pública. 17 jul. 2015. <www.apublica.org/2015/07/a-disputa-politicanas-periferias/>. 1 nov. 2016.

Herzer, Anderson. A queda para o alto. Petrópolis: Vozes, 1985.

Lajolo, Marisa. “Jeca Tatu em três tempos”. Os pobres na literatura brasileira. Roberto Schwarz, org. São Paulo: Brasiliense, 1983. 101-05.

Louzeiro, José. Infância dos mortos. Rio de Janeiro: Record, 1977.

Luna, Francisco Vidal, e Herbert S. Klein. "Mudanças sociais no período militar". A ditadura que mudou o Brasil. Daniel Aarão Reis, Marcelo Ridenti e Rodrigo Patto Sá Motta, orgs. Rio de Janeiro: Zahar, 2014. 66-91.

Napolitano, Marcos. 1964 - História do regime militar brasileiro. São Paulo: Contexto, 2014.

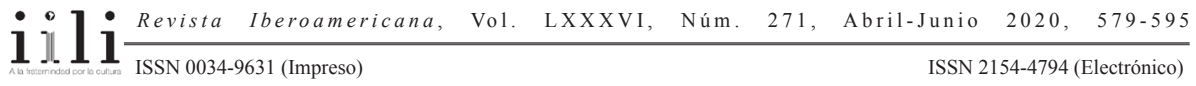


Nobre, Marcos. Choque de democracia - razões da revolta. São Paulo: Companhia das Letras, 2013.

O homem que virou suco. João Batista de Andrade, dir. Raíz Produções, 1980.

Pixote, a lei do mais fraco. Hector Babenco, dir. HB Filmes, 1980.

"Relatório da distribuição pessoal da renda e da riqueza da população brasileira". Secretaria de Política Econômica, 2016. <www.spe.fazenda.gov.br/noticias/ distribuicao-pessoal-da-renda-e-da-riqueza-da-populacao-brasileira/relatoriodistribuicao-da-renda-2016-05-09.pdf $>$.

Ribeiro, Darcy. O povo brasileiro: formação e o sentido do Brasil. 2a. ed. São Paulo: Companhia das Letras, 1996.

Rocha, João Cezar de Castro. "A guerra de relatos no Brasil contemporâneo. Ou: A 'dialética da marginalidade"'. Letras 28 (2004): 153-84.

Saad-Filho, Alfredo, e Armando Boito. "Brazil: The Failure of the PT and the Rise of the New Right." Socialist Register 52 (2016): 213-30.

Sant'Anna, André. O Brasil é bom. São Paulo: Companhia das Letras, 2014.

O paraíso é bem bacana. São Paulo: Companhia das Letras, 2006.

Schwarz, Roberto. “Apresentação”. Os pobres na literatura brasileira. Roberto Schwarz, org. São Paulo: Brasiliense, 1983. 7-8.

Um mestre na periferia do capitalismo. São Paulo: Duas Cidades/34, 2000.

Süssekind, Flora. “A poesia que foi à guerra". Folha de S. Paulo. 2 out. 2016: D14.

Palavras-chave: Direitos humanos; vulnerabilidade; André Sant'Anna; O Brasil é bom

Recebido: $\quad 15$ novembro 2016

Aprovado: $\quad 15$ maio 2017

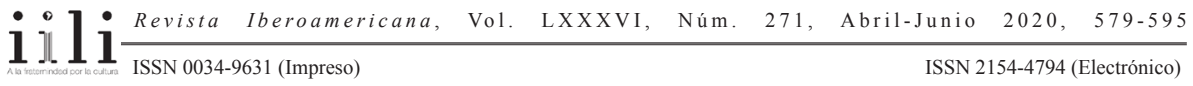


